\title{
The influence of the modification of acidic montmorillonites with polyacrylamide and copper deposition on $\mathrm{SCR}-\mathrm{NH}_{3}$ catalytic performance
}

\author{
Katarzyna Świrk ${ }^{1, *}$, Monika Motak ${ }^{1}$, Teresa Grzybek ${ }^{1}$, Cezary Czosnek $^{1}$, and Pawet Kniaź ${ }^{1}$ \\ ${ }^{1}$ AGH University of Science and Technology, Faculty of Energy and Fuels, Department of Fuel \\ Technology, Mickiewicza Av. 30, 30-059 Cracow, Poland
}

\begin{abstract}
The aim of this work was to study the influence of the modification of montmorillonites by carbonaceous and $\mathrm{Al}$ species as well as copper deposition. Commercial acid-treated montmorillonites, K5 and K30 (Sigma-Aldrich $\mathrm{GmBH}$ ), were modified and used as catalysts in Selective Catalytic Reduction process of nitrogen oxides by ammonia. The characterisation was carried out by low-temperature nitrogen sorption, Fourier-transform-infrared spectroscopy and X-ray diffraction. Catalytic performance in SCR-NH 3 of so-modified montmorillonites was compared under the following conditions: mass of catalyst: $200 \mathrm{~g}$, flow $100 \mathrm{~cm}^{3} / \mathrm{min}$, reaction mixture: $800 \mathrm{ppm} \mathrm{NO}, 800 \mathrm{ppm} \mathrm{NH}_{3}, 3 \% \mathrm{O}_{2}$, and $\mathrm{He}$. The modification with copper and polyacrylamide led to the increase in NO conversion. The studied catalysts showed low $\mathrm{N}_{2} \mathrm{O}$ formation.
\end{abstract}

\section{Introduction}

Directive 2010/75/EU introduced substantial reduction of NOx emissions from combustion of solid and liquid fossil fuels from $1^{\text {st }}$ of January 2016 [1]. The problem of a low-cost, efficient and environmentally friendly catalyst allowing to reduce NOx emissions has not yet been fully solved. Although the process of Selective Catalytic Reduction (SCR) used in industry to remove nitrogen oxides from the power plants is a well-established reaction, nevertheless, it requires the optimization of a number of aspects. The main problem is the currently applied industrial catalyst: $\mathrm{V}_{2} \mathrm{O}_{5} / \mathrm{WO}_{3} / \mathrm{TiO}_{2}$. Firstly, it is expensive. Secondly, it operates in the range of $300-400 / 450^{\circ} \mathrm{C}$ and thus is most often placed directly downstream of the SCR boiler, but upstream of the electrostatic precipitator and the desulfurization installation. This results in the catalyst deactivation caused by deposition of fly ash on its surface. At the same time co-firing of coal and biomass - the method used to reduce $\mathrm{CO}_{2}$ emissions - has a negative effect on the operation of the SCR catalyst placed in the front of dust collector because of alkali and alkaline earth elements present in biomass and, consequently, in the fly ash. It leads to deterioration of the catalyst by poisoning reaction centres [2]. Placing the catalyst downstream of the dust collector would therefore allow for

\footnotetext{
* Corresponding author: swirk@agh.edu.pl
} 
more efficient operation and longer catalysts life. However, this would require preheating of the flue gas to approximately $400 / 450^{\circ} \mathrm{C}$. Thus new catalysts, more efficient at lower temperatures, are needed. The development of such catalyst may allow the SCR installation to be placed downstream of ESP, or directly before the stack, eliminating the problem of catalyst deactivation caused by fly ash.

In this study commercial acid-treated montmorillonites K5 and K30, supplied by SigmaAldrich $\mathrm{GmBH}$, were modified and tested as catalysts in Selective Catalytic Reduction process of nitrogen oxides by ammonia.

\section{Experimental}

\subsection{Catalyst preparation}

Six samples of K5, and seven samples of K30 were modified with: alumina oligocations, followed by polymer treatment, with optional carbonization, and promoted with copper ( 5 wt. \%).

Table 1. Modification procedures of the studied samples

\begin{tabular}{|c|c|c|c|c|}
\hline $\begin{array}{c}\text { Sample } \\
\text { name }\end{array}$ & $\begin{array}{l}\text { Copper } \\
\text { deposit }\end{array}$ & $\begin{array}{l}\text { Alumina } \\
\text { pillaring }\end{array}$ & $\begin{array}{l}\text { Polymer } \\
\text { addition }\end{array}$ & Carbonization \\
\hline K5 & - & - & - & - \\
\hline $\mathrm{K} 5 \mathrm{Cu}$ & + & - & - & - \\
\hline $\mathrm{K} 5 \mathrm{Al}$ & - & + & - & - \\
\hline $\mathrm{K} 5 \mathrm{AlCu}$ & $+*$ & + & - & - \\
\hline $\mathrm{K} 5 \mathrm{AlGc}$ & - & + & + & + \\
\hline $\mathrm{K} 5 \mathrm{AlGcCu}$ & $+*$ & + & + & + \\
\hline K30 & - & - & - & - \\
\hline $\mathrm{K} 30 \mathrm{Cu}$ & + & - & - & - \\
\hline $\mathrm{K} 30 \mathrm{Al}$ & - & + & - & - \\
\hline $\mathrm{K} 30 \mathrm{AlCu}$ & $+*$ & + & - & - \\
\hline K30AlG & - & + & + & - \\
\hline K30AlGc & - & + & + & + \\
\hline $\mathrm{K} 30 \mathrm{AlGcCu}$ & $+*$ & + & + & + \\
\hline
\end{tabular}

*after alumina pillaring

The samples, derived from K5, were pillared with Al-polycations by chlorhydrol treatment according to the procedure performed by Vaughan [3] and described previously [4]. The modification of K30 materials was carried out according to Chmielarz et al. [5], with 
minor changes. K30-based catalysts were modified with a mixture of $\mathrm{NaOH}(0.4 \mathrm{M})$ and $\mathrm{AlCl}_{3}(0.4 \mathrm{M})$ with the molar ratio of $\mathrm{OH} / \mathrm{Al}=2.4$. After five days of aging at $65^{\circ} \mathrm{C}$ this solution was added to the 3 wt. \% suspension of K30, and the ratio between Al ions and K30 was set at $12 \mathrm{mmol}$ ions per $1 \mathrm{~g}$ of clay. The next step was filtration with Büchner funnel and washing with distilled water until $\mathrm{Cl}^{-}$ions were removed from the filtrate (test with $\mathrm{AgNO}_{3}$ ). Then the catalysts were dried for 24 hours at $100^{\circ} \mathrm{C}$, and subsequently calcined for 30 minutes at $500^{\circ} \mathrm{C}$.

Incipient wetness impregnation was performed for both $\mathrm{K} 5$ and $\mathrm{K} 30$-based samples with an aqueous solution of $\mathrm{Cu}\left(\mathrm{NO}_{3}\right)_{2}(5 \mathrm{wt} . \%$ of $\mathrm{Cu})$. The samples were treated either after pillaring $(\mathrm{K} 30 \mathrm{AlCu})$ or polymer treatment followed by carbonization $(\mathrm{K} 30 \mathrm{AlGcCu})$. In order to compare the influence of copper deposition, the raw material was also impregnated with copper $(\mathrm{K} 30 \mathrm{Cu})$.

The polymer treatment included mixing of $\mathrm{K} 5$ [4] and $\mathrm{K} 30$ with 3\% of polymer polyacryloamide using commercial product (Gigtar delivered by Zakłady Azotowe at Tarnów, Poland). After 72 hours of mixing montmorillonite samples were dried at $100^{\circ} \mathrm{C}$ for 12 hours. Next, carbonization was performed for 30 minutes at $500^{\circ} \mathrm{C}$ in argon atmosphere as proposed previously [6].

The samples designation and their modification procedures are summarized in Table 1.

\subsection{Catalyst characterisation}

Low-temperature sorption of nitrogen $\left(-196^{\circ} \mathrm{C}\right)$ was used to determine textural parameters of the prepared catalysts. The specific surface areas $\mathrm{S}_{\mathrm{BET}}$ for K5-based materials were examined by ASAP 2000 (Micromeritics), while for K30 series the measurements were performed by using Gemini VII 2390 (Micromeritics). Before the measurements the samples were degassed at $110^{\circ} \mathrm{C}$.

XRD measurements of the modified montmorillonities were carried out by Philips PV 3020 X' Pert (for K5), and PANalytical-Empyrean (for K30) diffractometer. The structure of the samples were determined with $\mathrm{CuK} \alpha(\lambda=1.5406 \AA)$ radiation source. The measurement range of $2 \theta=3-90^{\circ} \mathrm{C}$ was set.

\subsection{Catalytic performance}

The catalytic tests of $\mathrm{NO}$ reduction with $\mathrm{NH}_{3}$ (SCR) were performed for $200 \mathrm{mg}$ of catalyst placed in a fixed-bed microreactor. A thermocouple was used to control the temperature inside the catalytic bed. The composition of the inlet gas mixture was as follows: $800 \mathrm{ppm} \mathrm{NO}, 800 \mathrm{ppm} \mathrm{NH}_{3}, 3$ vol. $\% \mathrm{O}_{2}$ and He to balance. The total flow was $100 \mathrm{~cm}^{3} /$ min. In order to analyze the outlet concentrations of $\mathrm{NO}$ and $\mathrm{N}_{2} \mathrm{O}$, an IR detector $(\mathrm{ABB} 2020$ A0 series) was used. Before each SCR reaction, the catalysts were kept at $500^{\circ} \mathrm{C}$ for 30 minutes in helium atmosphere. The NO conversion [\%] was calculated using the following formula (1):

$$
N O_{\text {conversion }}=\left(N O_{\text {in }}-N O_{\text {out }}\right) / N O_{\text {in }} \cdot 100 \%
$$

where $\mathrm{NO}_{\text {in }}$ is the nitric oxide concentration at the reactor inlet [ppm], and $\mathrm{NO}_{\text {out }}$ at the outlet [ppm]. 


\section{Results and discussion}

\subsection{Low-temperature sorption of nitrogen}

Figure 1 presents an example of nitrogen sorption isotherm for $\mathrm{K} 30 \mathrm{AlGcCu}$. According to the IUPAC classification it represents isotherm type IV, indicating that montmorillonitebased materials have mesoporous structure. The shape of the hysteresis loop may be classified as $\mathrm{H} 4$ type which corresponds to the presence of homogeneous slit-shaped pores [7]. The isotherms recorded for other montmorillonites were similar to the one shown in Fig. 1.

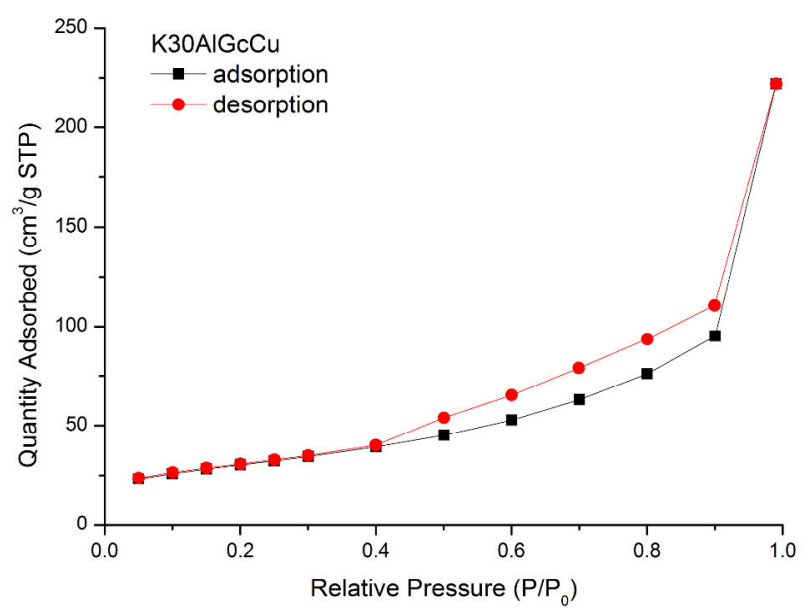

Fig. 1. Nitrogen sorption isotherm for $\mathrm{K} 30 \mathrm{AlGcCu}$

Table 2. Specific surface area $S_{B E T}$, mesopore volume $V_{\text {mes, }}$, micropore volume $V_{\text {mic }}$, and dominant pore size

\begin{tabular}{|l|r|r|r|r|}
\hline Catalyst & \multicolumn{1}{|c|}{$\begin{array}{c}\mathrm{S}_{\text {BET }} \\
{\left[\mathrm{m}^{2} / \mathrm{g}\right]}\end{array}$} & \multicolumn{1}{|c|}{$\begin{array}{c}\mathrm{V}_{\text {mes }} \\
{\left[\mathrm{cm}^{3} / \mathrm{g}\right]}\end{array}$} & $\begin{array}{c}\mathrm{V}_{\text {mic }} \\
{\left[\mathrm{cm}^{3} / \mathrm{g}\right]}\end{array}$ & $\begin{array}{c}\text { Pore } \\
\text { size } \\
{[\mathrm{nm}]}\end{array}$ \\
\hline $\mathrm{K} 30$ & 212 & 1.10 & 0.008 & 15.30 \\
\hline $\mathrm{K} 30 \mathrm{Cu}$ & 158 & 0.32 & $\mathrm{n} / \mathrm{d}$ & 5.99 \\
\hline $\mathrm{K} 30 \mathrm{Al}$ & 151 & 0.21 & 0.007 & 5.02 \\
\hline $\mathrm{K} 30 \mathrm{AlCu}$ & 153 & 0.27 & 0.009 & 6.19 \\
\hline $\mathrm{K} 30 \mathrm{AlG}$ & 142 & 0.24 & 0.009 & 5.57 \\
\hline $\mathrm{K} 30 \mathrm{AlGc}$ & 130 & 0.25 & 0.003 & 6.11 \\
\hline $\mathrm{K} 30 \mathrm{AlGcCu}$ & 107 & 0.53 & 0.005 & 11.1 \\
\hline
\end{tabular}

Table 2 shows textural parameters for the studied samples e.g. specific surface area, volume and size of dominant micro- and mesopores for K30 series. For K5 series, only specific surface areas were measured, and were equal to $164 \mathrm{~m}^{2} / \mathrm{g}, 152 \mathrm{~m}^{2} / \mathrm{g}, 128 \mathrm{~m}^{2} / \mathrm{g}, 78$ $\mathrm{m}^{2} / \mathrm{g}, 98 \mathrm{~m}^{2} / \mathrm{g}$ for $\mathrm{K} 5, \mathrm{~K} 5 \mathrm{Cu}, \mathrm{K} 5 \mathrm{Al}, \mathrm{K} 5 \mathrm{AlCu}$, and $\mathrm{KAlGcCu}$ samples, respectively [4]. The decrease in specific surface area after Al-pillaring was observed. This observation is rather 
hard to explain, since the XRD measurements resulted in the presence of (001) reflection; it will be discussed later in the text. However, it should be mentioned that similar effect was observed by Motak [4] for Milowice montmorillonite pillared by $\mathrm{Zr}$ or Al oligociations.

No increase in specific surface area was observed for K30 series after alumina intercalation. Therefore, the collapse of the structure for K30Al series most likely occurred. This assumption is supported by XRD results explained further in the text and is related to disappearance of the (001) reflection for Al-pillared K30 samples. One could speculate that instead of the intercalation, the deposition of alumina in the porous structure occurred, as suggested by pore volume decrease of $\mathrm{K} 30 \mathrm{Al}$ as compared to that of K30. Polymer modification, followed by carbonization, decreased the specific surface area further from 152 to $130 \mathrm{~m}^{2} / \mathrm{g}$, which is in agreement with the previous observations [4]. Dry impregnation with copper solution reduced the specific surface area of $\mathrm{K} 30 \mathrm{AlGcCu}$. In contrast, similar effect was not observed after the introduction of $\mathrm{Cu}^{2+}$ ions into $\mathrm{K} 30 \mathrm{Al}$.

\subsection{X-ray diffraction}

Fig. 2. shows diffraction patterns for K30-based materials. (001) reflection was observed only for the starting material $(\mathrm{K} 30)$, at $2 \theta=6.2^{\circ}$ with $\mathrm{d}_{001}=1.4 \mathrm{~nm} . \mathrm{d}_{001}$ calculated from the first low-angle diffraction maximum gives information about the interlayer distances in clays. Thus, the absence of this reflection may be interpreted as the partial collapse of the structure of K30Al-based samples, as previously observed for clay materials by Mahboub et al. [7].

$\mathrm{d}_{001}$ of $1.6 \mathrm{~nm}$ was registered for $\mathrm{K} 5 \mathrm{Al}, \mathrm{K} 5 \mathrm{AlG}$, and $\mathrm{K} 5 \mathrm{AlGCu}$, while for $\mathrm{K} 5$ it was equal to $1.3 \mathrm{~nm}$. This suggests at least partial intercalation for K5Al-based samples. The subsequent modifications of these samples, such as introduction of polymer, carbonization, and the deposition with copper, did not affect their structures [4].

The most intense reflection, which appears in all diffraction patterns, is associated with quartz $\left(\mathrm{SiO}_{2}\right)$, and it is a typical impurity for clay material $[8,9]$. Copper oxide $(\mathrm{CuO})$ was observed for $\mathrm{K} 30 \mathrm{Cu}$ which was impregnated with $\mathrm{Cu}^{2+}$, and calcined at $500^{\circ} \mathrm{C}$. Copper oxide reflections are assigned to angles $2 \theta=35.5^{\circ}, 38.7^{\circ}$. In the XRD patterns of other coppermodified catalysts, $\mathrm{CuO}$ presence was not observed. Perhaps $\mathrm{CuO}$ was in non-crystalline form and/or its crystallites were very small, which may suggest high dispersion of this metal oxide.
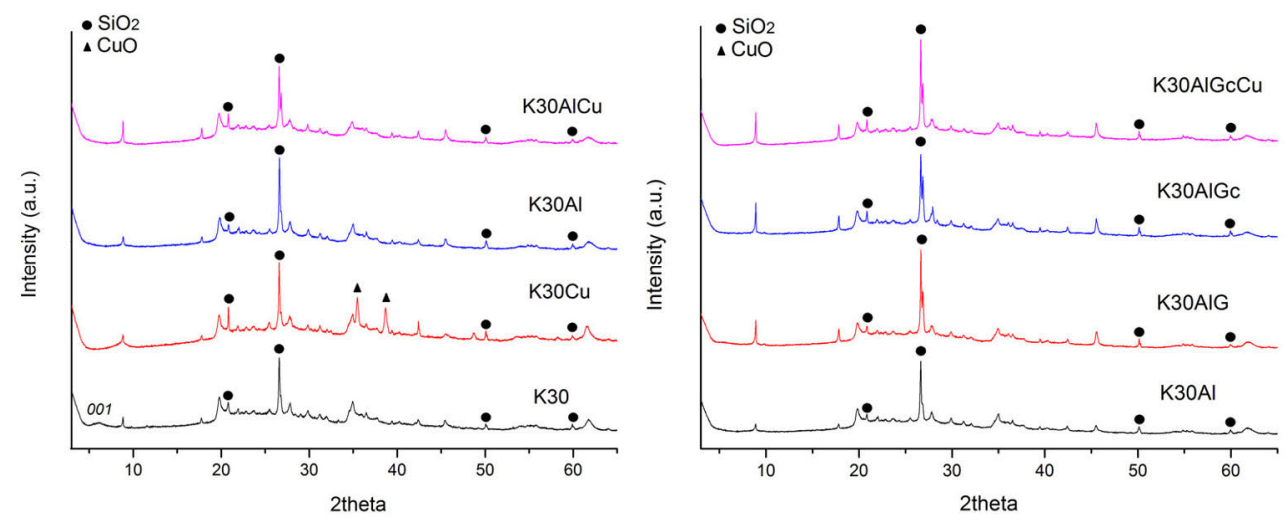

Fig. 2. XRD patterns for K30-based materials 
The comparison of XRD patterns for the selected samples is presented in Fig. 3. There is a noticeable increase of reflections at $2 \theta=26.86^{\circ}$ for samples which were carbonized (K30AlGc and $\mathrm{K} 30 \mathrm{AlGcCu}$ ). Graphite reflection occurs at ca. $27^{\circ}$ of $2 \theta$, thus it may suggest that carbon deposition on the surface of carbonised samples took place.

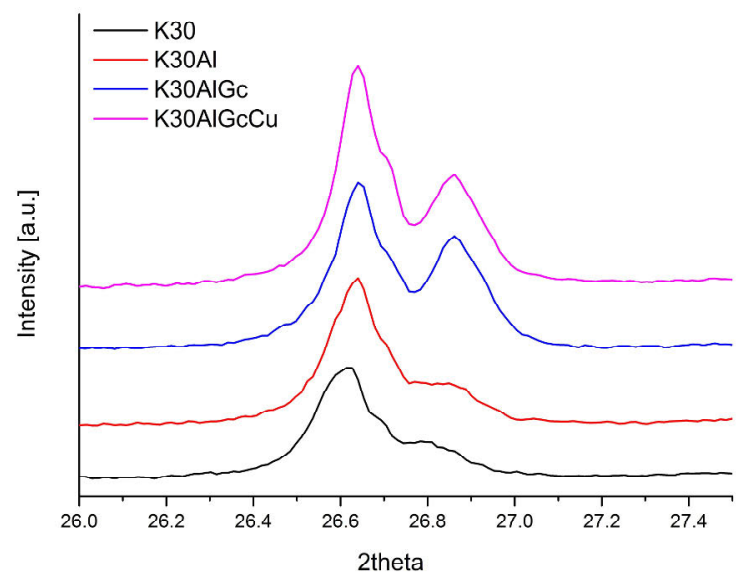

Fig. 3. XRD reflections for $\mathrm{K} 30, \mathrm{~K} 30 \mathrm{Al}, \mathrm{K} 30 \mathrm{AlGc}, \mathrm{K} 30 \mathrm{AlGcCu}$ in the range of $2 \theta=26-27.5^{\circ}$

\subsection{Catalytic tests}

Fig. 4. shows NO conversion versus temperature for montmorillonite-derived samples. For $\mathrm{K} 5$ series, NO conversion formed a sequence: $\mathrm{K} 5 \mathrm{AlGcCu}>\mathrm{K} 5 \mathrm{AlCu}>\mathrm{K} 5 \mathrm{Cu}>\mathrm{K} 5 \mathrm{AlGc}>$ $\mathrm{K} 5 \mathrm{Al}$. The same sequence was observed for K30-based carriers (K30AlGc> K30Al).

As may be derived from Fig. 4., at the low temperature region $\left(200-250^{\circ} \mathrm{C}\right)$ carbon deposition increased NO conversion, which was almost two times higher in comparison to the samples without carbonization step. Possibly carbon played a role as a second reducing agent, as suggested by Motak [4]. The catalysts $\mathrm{K} 5 \mathrm{AlGcCu}$ and $\mathrm{K} 30 \mathrm{AlGcCu}$ maintained NO conversion above $80 \%$ at 250 and $300^{\circ} \mathrm{C}$. The activity of the catalysts based on $\mathrm{K} 30$ at $250^{\circ} \mathrm{C}$ followed a sequence: $\mathrm{K} 30 \mathrm{AlGcCu}>\mathrm{K} 30 \mathrm{Cu}>\mathrm{K} 30 \mathrm{AlCu}$.
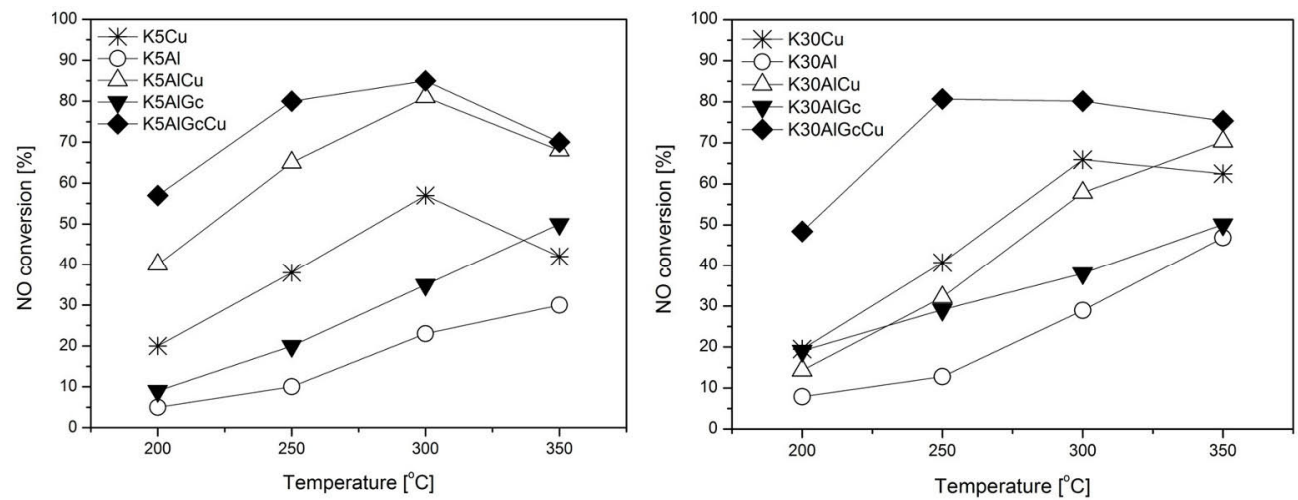

Fig. 4. NO conversion versus temperature for K5-, and K30-based materials.

Fig. 5. shows $\mathrm{N}_{2} \mathrm{O}$ formation during catalytic tests. It should be mentioned that $20 \mathrm{ppm}$ are below detection limit of the method used, therefore only values above $20 \mathrm{ppm}$ should be 
considered. The $\mathrm{N}_{2} \mathrm{O}$ formation was low for carriers and catalysts up to $350^{\circ} \mathrm{C}$, and it did not exceed 65 ppm. K30-based samples showed slightly lower amount of $\mathrm{N}_{2} \mathrm{O}$ in the postreaction mixture.
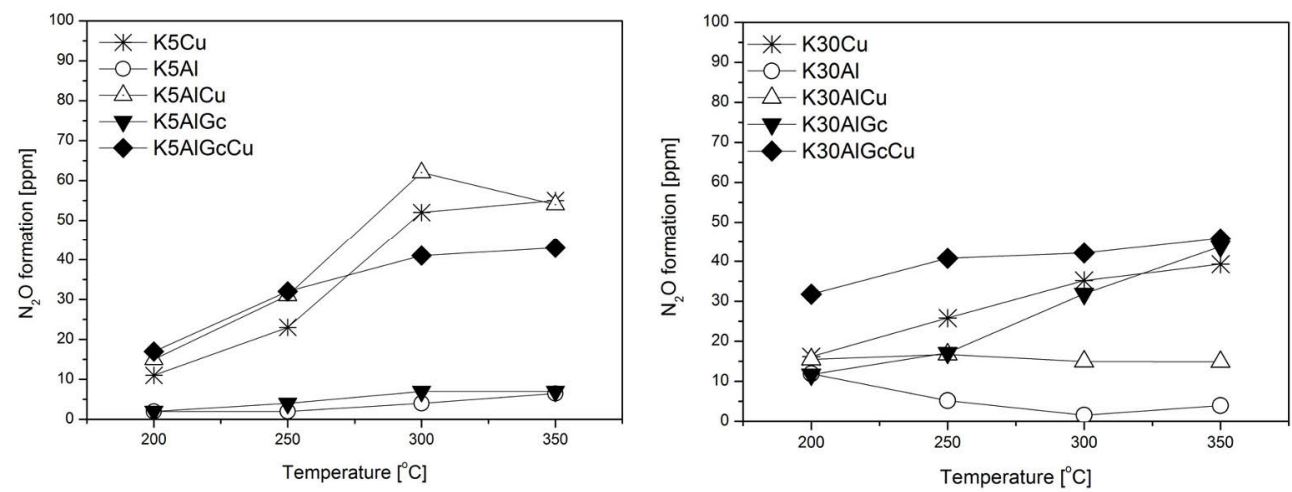

Fig. 5. $\mathrm{N}_{2} \mathrm{O}$ formation versus temperature for K5-, and K30-based materials.

In case of K5-based materials the introduction of copper led to an increase of $\mathrm{N}_{2} \mathrm{O}$ amount. This was not observed for $\mathrm{K} 30 \mathrm{AlCu}$, for which $\mathrm{N}_{2} \mathrm{O}$ formation remained stable at very low level (less than $20 \mathrm{ppm}$ ). This indicates that $\mathrm{N}_{2} \mathrm{O}$ formation is strongly dependent on the sample preparation procedure, since modification by $\mathrm{Al}$ oligocations was carried out in a different way for K30 than for K5 series.

\section{Conclusions}

Two series of catalysts, based on the commercial montmorillonite $\mathrm{K} 5$ and $\mathrm{K} 30$, modified with alumina pillaring, carbon deposition and copper impregnation were characterised by low-temperature nitrogen adsorption and $\mathrm{X}$-ray diffraction. The activity and selectivity of the catalysts in the SCR-NH${ }_{3}$ process were tested for the mixture of $800 \mathrm{ppm} \mathrm{NO}, 800 \mathrm{ppm} \mathrm{NH}_{3}$, and $3 \% \mathrm{O}_{2}$ in $\mathrm{He}$.

Based on the low-temperature nitrogen sorption studies a decrease in surface area was observed after introduction of alumina oligocations into montmorillonite. The polyacrylamide modification followed by carbonization, and copper deposition for montmorillonites catalysts decreased the specific surface area even further.

$\mathrm{X}$-ray diffraction showed $\mathrm{d}_{001}$ of $1.6 \mathrm{~nm}$ for $\mathrm{K} 5 \mathrm{Al}, \mathrm{K} 5 \mathrm{AlG}$, and $\mathrm{K} 5 \mathrm{AlGCu}$, while for $\mathrm{K} 5$ it was equal to $1.3 \mathrm{~nm}$, indicating that pillaring was successful and the modification with polymer and copper oxide did not further influence the structure of studied clays. In the case of K30-series, the reflection (001) was observed only for the starting material at $2 \theta=6.168^{\circ}$, corresponding to $\mathrm{d}_{001}$ of $1.4 \mathrm{~nm}$. The absence of (001) reflection in diffraction patterns of other K30-based samples may suggest a collapse of the clay structure.

The catalytic tests exhibited high activity of the modified montmorillonite samples in the process of $\mathrm{NH}_{3}-\mathrm{SCR}$. Better results were observed for the catalysts modified with polymer and carbonaceous deposit as compared to the samples modified with only Al-oligocations. Additional copper deposition on carbonised samples resulted in a significant increase in catalytic activity. The modification with $\mathrm{Cu}$ improved the catalytic performance of each catalyst treated by this metal. The quantity of $\mathrm{N}_{2} \mathrm{O}$ produced for all samples was low and did not exceed $65 \mathrm{ppm}$. 
On the whole, the introduction of copper oxides, Al oligocations treatment, as well as treatment with polyacrylamide, and carbonization positively affected catalytic activity and did not decrease selectivity to nitrogen.

Acknowledgements AGH 11.11.210.213

\section{References}

1. Directive 2010/75/EU of the European parliament and of the Council, Offical Journal of the European Union (2010)

2. M. Kiełtyka, A.P. Doares Dias, H. Kubiczek, B. Sarapata, T. Grzybek, CR Chimie, 18, $1036(2015)$

3. D. E. W. Vaughan, R. J. Lussier, in: W. Rees (Ed.), Proc. 5th Int. Conf. Zeolites, 94 (1980)

4. M. Motak, Catal Today, 137, 247 (2008)

5. L.Chmielarz, P. Kuśtrowski, M. Zbroja, B. Gil-Knap, J. Datka, R. Dziembaj, Appl Catal B-Environmental 53, 46 (2004)

6. T. Grzybek J. Klinik. M. Motak, H. Papp, M. Żyła, J. Colloid Interface Sci. 227, 291 (2000)

7. R. Mahboub, Y. El Mouzdahir, A. Elmchaouri, A. Carvalho, M. Pinto, J. Pires, Colloids Surf. A 280, 81 (2006)

8. L.Chmielarz, Naturalne krzemiany warstwowe jako materiały do syntezy katalizatorów dla procesu DeNOx, in: Adsorbenty i Katalizatory, Wybrane technologie a środowisko, 7 (2012)

9. V. Tabernero, C. Camejo, P. Terreros, M. Dolores Alba, T. Cuenca, Materials 3, 1015 (2010) 